\title{
THE
}

\section{Using Long-Term Constant-Effort Banding Data to Monitor Population Trends of Migratory Birds: A 33-Year Assessment of Adjacent Coastal Stations}

\author{
Jason E. Osenkowski \\ Peter W. C. Paton \\ University of Rhode Island, ppaton@uri.edu \\ Douglas Kraus
}

Follow this and additional works at: https://digitalcommons.uri.edu/nrs_facpubs

Terms of Use

All rights reserved under copyright.

\section{Citation/Publisher Attribution}

Jason E. Osenkowski, Peter W. C. Paton, Douglas Kraus, "Using Long-Term Constant-Effort Banding Data to Monitor Population Trends of Migratory Birds: A 33-Year Assessment of Adjacent Coastal Stations," The Condor 114(3), (1 August 2012). https://doi.org/10.1525/cond.2012.110169 . Submission: Received: 13 October 2011; Accepted: 29 February 2012

Available at: http://dx.doi.org/10.1525/cond.2012.110169

This Article is brought to you for free and open access by the Natural Resources Science at DigitalCommons@URI. It has been accepted for inclusion in Natural Resources Science Faculty Publications by an authorized administrator of DigitalCommons@URI. For more information, please contact digitalcommons-group@uri.edu. 


\title{
Using Long-Term Constant-Effort Banding Data to Monitor Population Trends of Migratory Birds: A 33-Year Assessment of Adjacent Coastal Stations
}

\author{
Author(s): Jason E. Osenkowski , Peter W. C. Paton and Douglas Kraus \\ Source: The Condor, 114(3):470-481. 2012. \\ Published By: Cooper Ornithological Society \\ URL: http://www.bioone.org/doi/full/10.1525/cond.2012.110169
}

BioOne (www.bioone.org) is a nonprofit, online aggregation of core research in the biological, ecological, and environmental sciences. BioOne provides a sustainable online platform for over 170 journals and books published by nonprofit societies, associations, museums, institutions, and presses.

Your use of this PDF, the BioOne Web site, and all posted and associated content indicates your acceptance of BioOne's Terms of Use, available at www.bioone.org/page/terms_of_use.

Usage of BioOne content is strictly limited to personal, educational, and non-commercial use. Commercial inquiries or rights and permissions requests should be directed to the individual publisher as copyright holder. 


\title{
USING LONG-TERM CONSTANT-EFFORT BANDING DATA TO MONITOR POPULATION TRENDS OF MIGRATORY BIRDS: A 33-YEAR ASSESSMENT OF ADJACENT COASTAL STATIONS
}

\author{
Jason E. Osenkowski ${ }^{1}$, Peter W. C. Paton ${ }^{2}$, and Douglas Kraus ${ }^{3}$ \\ Department of Natural Resources Science, University of Rhode Island, Kingston, RI 02881
}

\begin{abstract}
One technique for monitoring population trends of many species of migratory songbirds is to assess changes in population indices at constant-effort mist-netting stations located at sites of migration stopover. However, few studies have attempted to validate this approach. We compared long-term (1969-2001) population trends based on annual variation in capture rates at two banding stations located $30 \mathrm{~km}$ apart in southern Rhode Island, with one on the mainland, the other on an offshore island. Of 24 species with sufficient sample sizes, 21 species exhibited a significant linear decline at one or both stations. There was a high degree of conformity in trend-slope directions observed at each station. Annual fluctuations and trend magnitude conformed less well, although there was more concordance for nine transient species that do not breed in southern New England. At both stations trends were similar to those at a migration-monitoring station $\sim 95 \mathrm{~km}$ away in coastal Massachusetts. The trends at this network of three migration-monitoring stations were more negative than those of Breeding Bird Surveys in northern New England and southeastern Canada. Our results demonstrate that constant-effort mist-netting stations could be used to monitor population trends of many species of migratory songbirds, although it is not clear which breeding populations are being monitored. This suggests that banding stations could be used to supplement existing large-scale monitoring programs.
\end{abstract}

Key words: $\quad$ banding, capture rates, mist netting, passerines, population trends, Rhode Island.

Uso de Datos de Esfuerzos Constantes de Anillado de Largo Plazo para Monitorear las Tendencias Poblacionales de Aves Migratorias: Una Evaluación de 33 Años en Estaciones Costeras Adyacentes

Resumen. Una técnica para el monitoreo de las tendencias poblacionales de muchas especies de aves migratorias es evaluar cambios en los índices poblacionales obtenidos en estaciones con esfuerzo constante de captura con redes de niebla localizadas en sitios de parada migratoria. Sin embargo, pocos estudios han intentando validar este enfoque. Comparamos las tendencias poblacionales de largo plazo (1969-2001) basados en la variación anual en las tasas de captura en dos estaciones de anillado localizadas a $30 \mathrm{~km}$ de distancia al sur de la Isla Rhode, con una en el continente y otra en una isla mar adentro. De las 24 especies con tamaño de muestra suficiente, 21 exhibieron una disminución lineal significativa en una o las dos estaciones. Hubo un alto grado de conformidad en las direcciones de tendencia de la pendiente observadas en cada estación. Las fluctuaciones anuales y la tendencia de la magnitud se ajustaron menos adecuadamente, aunque hubo más concordancia para nueve especies pasajeras que no crían en el sur de Nueva Inglaterra. En ambas estaciones, las tendencias fueron similares a aquellas de una estación de monitoreo migratorio situada a $\sim 95 \mathrm{~km}$ en la costa de Massachusetts. Las tendencias en esta red de tres estaciones de monitoreo migratorio fueron más negativas que las del Conteo Reproductivo de Aves en el norte de Nueva Inglaterra y el sureste de Canadá. Nuestros resultados demuestran que las estaciones de esfuerzo constante de captura con redes de niebla pueden ser usadas para monitorear las tendencias poblacionales de muchas especies migratorias de aves canoras, aunque no está claro qué poblaciones reproductivas están siendo monitoreadas. Esto sugiere que las estaciones de anillado pueden ser usadas para fortalecer los programas existentes de monitoreo a largo plazo.

\section{INTRODUCTION}

Constant-effort mist-netting stations are used throughout North America to assess changes in population indices of songbirds along migratory routes (Porzig et al. 2011), yet few studies have critically assessed estimates of long-term population trends derived from migration-monitoring stations (Ballard et al.
2003, Lloyd-Evans and Atwood 2004, Rimmer et al. 2004). The validity of estimates of long-term population trends derived from migration-monitoring stations has been criticized for several reasons. First, biologists are often uncertain about the origin or destination of birds captured at such stations and thus do not know which populations are being monitored (Dunn and Hussell 1995, but see Wassenaar and Hobson 2001). Second,

Manuscript received 13 October 2011; accepted 29 February 2012.

${ }^{1}$ Current address: Department of Environmental Management, Division of Fish and Wildlife, 277 Great Neck Road, West Kingston, RI.

E-mail: jay.osenkowski@dem.ri.gov

${ }^{2}$ Corresponding author; e-mail: ppaton@mail.uri.edu

${ }^{3}$ Deceased.

The Condor, Vol. 114, Number 3, pages 470-481. ISSN 0010-5422, electronic ISSN 1938-5422. @ 2012 by The Cooper Ornithological Society. All rights reserved. Please direct all requests for permission to photocopy or reproduce article content through the University of California Press's Rights and Permissions website, http://www.ucpressjournals.com/ reprintInfo.asp. DOI: 10.1525/cond.2012.110169 
changes in habitat at monitoring stations could influence capture rates in a way unrelated to actual population trends (Remsen and Good 1996, Pagen et al. 2002). Third, the probability of a bird being captured in a mist net varies by species, so some species are under- or oversampled at such stations, and these stations are not appropriate for all species (Wang and Finch 2002, Mallory et al. 2004). Finally, capture rates can be affected by local and regional weather patterns and other factors independent of population trends (Dunn 2005).

Since 1966, one primary large-scale monitoring program for passerines in North America has been the Breeding Bird Survey (BBS), which uses point counts within breeding habitat along thousands of roadside routes throughout the United States and Canada (Sauer et al. 2003). However, the BBS provides imprecise trend estimates for many species, including those that occur at low densities, interior-forest species, and boreal species (Rich et al. 2004, Bart et al. 2004). One alternative approach to monitoring the population trends of some species is to assess changes in population indices at constanteffort mist-netting stations located along migratory routes (Dunn and Ralph 2004, Porzig et al. 2011). This approach is widely used in Canada, where over 20 stations have been monitoring bird populations during spring and fall migration for over a decade (Crewe et al. 2008).

Several North American studies have estimated population trends of migrants by means of long-term banding data from constant-effort mist-netting stations (Dunn et al. 1997, Lloyd-Evans and Atwood 2004, Rimmer et al. 2004). To test the validity of migration-count data for assessing long-term population trends, several investigators compared changes in capture rates at banding stations to trend estimates from areas surveyed by the BBS, with most studies demonstrating encouraging levels of concordance (Dunn et al. 1997, Francis and Hussell 1998, Ballard et al. 2003, Lloyd-Evans and Atwood 2004, Crewe et al. 2008). However, since the origin of birds captured at migration stations is uncertain, it is challenging for researchers to select the BBS regions appropriate for comparative analyses. Moreover, it is often difficult to determine which survey method portrays a species' actual population trends when there are discrepancies between those estimated from the BBS and those estimated from banding stations (Ballard et al. 2003, Lloyd-Evans and Atwood 2004).

Another approach to testing the validity of trend estimates from migration-monitoring stations is to compare results from nearby stations (Dunn et al. 2007, Lloyd-Evans and Atwood 2004, Rimmer et al. 2004, Crewe et al. 2008). If banding stations are capable of monitoring populations over large spatial scales, then there should be concordance in trends obtained from nearby banding stations regardless of the magnitude of capture rates because the stations are presumably sampling from the same population of migrants. Dunn et al. (1997) documented positive correlations between annual indices in eight of nine transients at two neighboring $(0.75 \mathrm{~km}$ apart) banding stations in Kalamazoo, Michigan, and with BBS trends for Ontario and Michigan. In contrast, Hagan et al. (1992) found few correlations between population-trend estimates at two migration-monitoring stations located about $750 \mathrm{~km}$ apart (Manomet, Massachusetts, and Powdermill Nature Reserve, Pennsylvania), Rimmer et al. (2004) found no relationship between capture rates at two stations $250 \mathrm{~km}$ apart in Massachusetts and Vermont, and Crewe et al. (2008) found positive correlations in annual indices at stations less than $2000 \mathrm{~km}$ apart. One explanation for the lack of relationships between stations that are far apart is that they were sampling different regional breeding populations.

Here we compare long-term (33 years, 1969-2001) population trends at two Atlantic coastal banding stations situated $30 \mathrm{~km}$ apart in southern Rhode Island, one on the mainland, the other offshore on Block Island. Given the close proximity of these two stations, we assumed that trends and annual fluctuations would be positively correlated. However, the suitability of coastal sites for monitoring avian population trends is uncertain because age ratios of birds captured along the Atlantic coast are biased toward juveniles (Drury and Keith 1962), which Ralph (1981) termed the "coastal effect." The effect may be due to the behavior of adults and juveniles differing near large bodies of water (Dunn and Nol 1980). We know of no studies that have investigated whether long-term trend estimates based on data from an offshore migration station, inherently biased toward juveniles, differ from those based on data from nearby mainland sites.

We also compare trends from our two study sites to two other independent sources of data. First, we compare trends for selected species to those based on data from the Manomet Center for Conservation Sciences (hereafter Manomet), Plymouth, Massachusetts (Lloyd-Evans and Atwood 2004). We also compare our estimates to data from BBS routes in northeastern North America. Lloyd-Evans and Atwood (2004) found that rates of capture by mist net of many species of fall migrants at Manomet were significantly correlated with BBS results from southern and northern New England.

\section{METHODS}

\section{STUDY AREAS}

Our study sites in southern Rhode Island were Kingston Wildlife Research Station (KWRS; $41^{\circ} 27^{\prime} \mathrm{N}, 71^{\circ} 31^{\prime} \mathrm{W}$ ) and Block Island Banding Station (BIBS; $41^{\circ} 12^{\prime} \mathrm{N}, 71^{\circ} 35^{\prime} \mathrm{W}$ ). KWRS (33 ha) is located in the town of South Kingstown, $6.5 \mathrm{~km}$ north of the Atlantic Ocean, on land that was formerly a farm, abandoned in the 1920s. By the mid-1950s when mist netting was initiated, over $85 \%$ of the station was forested, and the forest continued to mature through the study. In addition, since the 1940s, forests have expanded to some of the former agricultural fields on the property. However, the habitat in the area immediately 
surrounding the mist nets remained relatively constant through the study, with most nets located at edges between forest and former agricultural fields. After 2001, early-successional habitat near mist nets was manipulated, so we summarize capture histories up to 2001 only. The overstory at KWRS was dominated by oak (Quercus spp.), American ash (Fraxinus americana), and red maple (Acer rubrum); the understory was composed of common privet (Ligustrum vulgare), Morrow's honeysuckle (Lonicera morrowii), bull brier (Smilax rotundifolia), highbush blueberry (Vaccinium corymbosum), oriental bittersweet (Celastrus orbiculata), fox grape (Vitis labrusca), and poison ivy (Toxicodendron radicans).

Block Island Banding Station (BIBS) is located $30 \mathrm{~km}$ south of KWRS and $17.5 \mathrm{~km}$ south of mainland Rhode Island in the Clay Head Sanctuary at the northern end of Block Island, where large numbers of migratory birds can be captured (Reinert et al. 2003). This $25-\mathrm{km}^{2}$ island extends $9.7 \mathrm{~km}$ from north to south and narrows abruptly at its northern tip. In the early 1970s, herbaceous vegetation and low shrubs dominated the flora at BIBS (Reinert et al. 2003). In 2002 , the vegetation was dominated by 2 - to 3 -m-tall shrubs including bayberry (Myrica pensylvanica), arrowwood ( $\mathrm{Vi}$ burnum dentatum), multiflora rose (Rosa multiflora), poison ivy, and shadbush (Amelanchier canadensis).

Lloyd-Evans and Atwood (2004) monitored avian migration at Manomet, along the coast of Cape Cod Bay in Plymouth County, Massachusetts $\left(41^{\circ} 50^{\prime} \mathrm{N}, 70^{\circ} 30^{\prime} \mathrm{W}\right)$. Vegetation at this station is dominated by second-growth deciduous forests primarily of black cherry (Prunus serotina), shadbush (Amelanchier sp.), red maple, white oak (Quercus alba), and pitch pine (Pinus rigida).

At all three stations, birds were captured in 4-panel nylon mist nets, mesh 30 and $36 \mathrm{~mm}, 2.6 \mathrm{~m}$ high by $12 \mathrm{~m}$ long. At KWRS, nets were operated from the first week of August through mid-November from 1956 through 2001, except for 1995 through 1997 when the station was not in operation. At BIBS, nets were operated annually from mid-August to midNovember from 1967 to 2001. Manomet operated 45-50 nets annually from 1970 to 2001, with nets generally open from $0.5 \mathrm{hr}$ before sunrise to $0.5 \mathrm{hr}$ after sunset from 15 August to 15 November (Lloyd-Evans and Atwood 2004). At both KWRS and BIBS, most mist nets were kept at the same locations throughout the study. Thus, as vegetation at each site grew through the study, its composition and structure near the nets also changed. Supplementary nets were occasionally added or removed at both sites throughout the study. As a result, the number, location, and duration of daily operation of the nets varied annually. However, each station recorded daily net-hours, so we were able to calculate daily capture rates (number of birds captured per net-hour, where 1 net-hr $=1$ net open for $1 \mathrm{hr}$ ) for each site to account for variation in the hours of operation. Mist nets were typically opened $30 \mathrm{~min}$ before sunrise and closed by 12:00 at KWRS and by sunset at BIBS.
At KWRS, from 1969 to 1994, Kraus typically operated four nets daily for an average of $772(\mathrm{SE}=37)$ net-hr per year for $55(\mathrm{SE}=1.7)$ days per year. From 1998 to 2001, biologists from the University of Rhode Island took over banding at KWRS, opening 10 nets daily for an average of $3443(\mathrm{SE}=83)$ net-hr per year for an average $74(\mathrm{SE}=0.6)$ days per year. At BIBS, Elise Lapham and colleagues usually opened 10-14 mist nets daily for an average of $5775(\mathrm{SE}=331)$ net-hr per year for 31 to 64 days per year.

To compare avian population indices at KWRS and BIBS, we imposed several restrictions. First, we used only data collected from 15 August to 31 October, 1969-2001, exclusive of 1995-1997, and included only birds captured before 12:00. Second, we calculated species-specific migration windows by eliminating the outer $5 \%$ of captures, a criterion based on the Julian date of capture weighted by the total number of captures. Migration windows were species-specific because migration phenology varied by species. For some species, lingering or nonmigrating individuals likely remained in the data, but our cutoff reduced the number of these individuals, and we only included first captures. Furthermore, we eliminated resident species from this analysis (Enser 1992). To meet the sample-size assumptions of parametric tests, we included only species of which at least three individuals were captured per year in at least $80 \%$ of the years at either KWRS or BIBS. Also, we required that the total number of captures of each species at each site be at least twice as large as the number of years in the analysis $(n=60)$.

We categorized species into three guilds based on their migration strategy, as neotropical migrants, if they breed in North America and winter in the Caribbean or Central or South America, nearctic migrants if they breed and winter in North America, or mixed-distance migrants if they breed in North America and winter in the Caribbean, North, Central, or South America (AOU 1998, DeGraaf and Rappole 1995). Within these broad classifications, we further identified species as transients if they do not breed in southern Rhode Island (Enser 1992).

We corrected, to the extent possible, for variable banding effort by calculating capture rates. For each species, the capture rate was the total number of individuals captured on a given date divided by the number of net-hours for that date and multiplied by 100 to give birds captured per 100 net-hours (Hagan et al. 1992, Dunn and Hussell 1995).

We compared trends estimated from the three constanteffort mist-netting stations to trends from Breeding Bird Survey routes located in four bird conservation regions (BCR; NABCI 2011) and pooled routes in eastern North America. On the basis of the breeding ranges of the most common species captured at the banding stations, we analyzed BBS trend estimates from regions including New England/Mid-Atlantic States (BCR 30), Northern Atlantic Forests (BCR 14), Boreal Hardwood Transition (BCR 12), and Boreal Softwood Shield (BCR 8). 


\section{STATISTICAL ANALYSES}

For most species, migration counts are highly skewed (Dunn and Hussell 1995, Dunn et al. 1997). Therefore, we used a logarithmic transformation (natural $\log$ ) on the daily counts, with a constant of 1.0 added before the transformation. This transformation normalized the data and converted multiplicative effects into additive ones (Zar 2010). The final daily index was represented as:

$$
\mathrm{DI}=\ln \left(\left[\left\{\frac{N_{\mathrm{jk}}}{H_{\mathrm{jk}}}\right\} \times 100\right]+1\right)
$$

where $N$ is the number of individuals counted and $H$ is the number of net-hours on day $k$ in year $j$.

The log-transformed daily indices were the dependent variable in the regression, while the independent variables were Julian date, Julian date ${ }^{2}$, year, year ${ }^{2}$, and year ${ }^{3}$. We set the midpoint Julian date to 0 for each species-specific migration window. It was also necessary to set the midpoint year to 0 (e.g., $1982=-1,1983=0,1984=1)$, which forced symmetry in the data. We used multiple regression to identify those values that contributed to the poor distribution of residuals (Hussell 1981). This provided an objective method for eliminating those dates on which unstandardized predicted values were less than 0 to improve the distribution of the residuals (Hussell et al. 1992) while also improving the data set to include only individuals within a clearly delineated migration window. All subsequent analyses were of this reduced data set.

We performed a second multiple regression to obtain annual indices for each species. The independent variables included 29 dummy variables for year (one reference year, 1983, excluded), with first- through third-order Julian date terms (with the midpoints set to 0 ) entered as covariates. The addition of date terms allowed for the detection of systematic variation in bird numbers with respect to date. By adding date terms, we controlled for date effects (Dunn et al. 1997), adjusting annual indices for days during the study when nets were not open but numbers of migrating birds were expected to be high. The model is represented as

$$
\mathrm{AI}_{j}=\alpha_{0}+\beta_{1} \bar{J}+\beta_{2} \bar{J}^{2}+\beta_{3} \bar{J}^{3}+\delta_{j}
$$

where AI is the annual index for year $j(1969,1970, \ldots), \alpha$ is the intercept, $\beta_{1}, \beta_{2}$ and $\beta_{3}$ are the coefficients of the Julian date terms, $\bar{J}, \bar{J}^{2}$, and $\bar{J}^{3}$ are means of Julian date terms, and $\delta$ is the coefficient for the dummy variable in year $j$.

To obtain indices in the untransformed scale, we added 0.5 of the error variance and then back-transformed the data. The estimates in the original back-transformed scale represent the mean rather than the median count (Sprugel 1983). We also subtracted 1.0 from the back-transformed indices:

$$
\text { back-transformed } \mathrm{AI}_{j}=e^{\left(\mathrm{AI}_{j}+\right.\text { error variance/2) }}-1
$$

where AI is the annual index for year $j$ and $e$ is the antilog of the natural logarithm. Annual indices presented in the results always imply, unless otherwise specified, the back-transformed indices and represent an estimate of the mean number of birds captured per 100 net-hr under standardized date conditions.

We calculated trend estimates for each species from the back-transformed annual indices. We used linear regression of log-transformed indices on year to obtain trend estimates that represent an annual percent rate of change (Geissler and Noon 1981). By calculating linear trend estimates, we were able to make direct comparisons with BBS trend estimates.

We compensated for variations in the precision of the data by weighting cases in the trend analysis. Years with a greater number of net-hours on more days were assigned a greater weight in the analysis. Weighting cases was particularly important because of annual differences in effort at both banding stations. We used proportional net-hours as a weighting variable throughout the analysis, as described by Osenkowski (2002).

We tested for significant differences between sites by comparing differences in slope. We included the log-transformed annual indices as the dependent variable. Independent variables in this analysis were year, a dummy variable for site, and a year $\times$ site interaction term. By testing slopes, we were able to determine the magnitude of differences in trends.

We made several comparisons between BIBS and KWRS to determine if these stations were tracking populations similarly. First, we compared actual annual indices, which are influenced by the long-term trend, using two-tailed Spearman rank correlations. We also compared annual detrended indices at the sites. We obtained detrended indices for correlation analysis from the bestfitting significant trend (up to third-order polynomials). These residuals were obtained from the log-transformed annual indices used in the trend analysis. Correlations between the actual annual indices could arise if there was a strong trend at both sites, if there were strong yearly fluctuations, or if there were both a strong trend and strong yearly fluctuations. However, detrended indices are likely to be correlated only if there are corresponding yearly fluctuations at both sites. We performed two-tailed Pearson product-moment correlations on the detrended indices because the data met the assumptions of parametric tests. For trend estimates, we also made comparisons by two-tailed Spearman rank correlations. Finally, for each species, we tested for conformity in slope direction at banding stations with a likelihood ratio test.

\section{REGIONAL TREND COMPARISON}

We attempted to eliminate captures that may have reflected local dispersal during the breeding season. For comparison of regional population trends, we included only those species identified as transients, although some of these species winter in southern New England.

We compared trend estimates from KWRS and BIBS to those from Manomet (Lloyd-Evans and Atwood 2004), $95 \mathrm{~km}$ from KWRS located and $117 \mathrm{~km}$ from BIBS. We also used BBS data (analyzed by estimating equations, Sauer et al. 2011) to compare regional trends to those at KWRS, BIBS, and Manomet. We compared changes in abundance of the same species over the 
same period, except that data from Manomet and the BBS included 1995-1997 and data from Manomet were from 1970 to 2001. Because we were uncertain of the breeding origins of the populations captured at our banding stations, we compared two BBS trends in two regions, northern New England and closed boreal forests, the most likely origins of the majority of captured individuals (Lloyd-Evans and Atwood 2004). For regional trend comparisons we used two-tailed Spearman rank correlations.

If species is in decline, then early detection of the decline is critical. The likelihood of commission of a type II error has more severe consequences for a declining species (Caughley and Gunn 1996). As a result, we set an a priori $\alpha$ level at $P<0.10$ for detecting a significant trend. However, in correlation analyses and tests for differences in slope, we used a more conventional $\alpha$ level of $P<0.05$. For all statistical analyses we used SPSS (SPSS, Inc. 2007).

\section{RESULTS}

There were 24 species that met the sample-size criteria, 11 neotropical migrants, 11 nearctic migrants, and 2 mixed-distance migrants. The 9 species of transients not breeding in southern Rhode Island included 4 neotropical migrants and 5 nearctic migrants (Table 1). At KWRS, there were significant linear declines in $64 \%$ of neotropical migrants, $72 \%$ of nearctic migrants, and both mixed-distance migrants (Fig. 1); at BIBS, there were significant linear declines in $91 \%$ of neotropical migrants, $45 \%$ of nearctic migrants, and neither mixed-distance

TABLE 1. Estimated linear trends (\% change per year) from 1969 to 2001 of 24 species of fall migrants captured at two constant-effort mistnetting stations, Kingston Wildlife Research Station (KWRS) and Block Island Banding Station (BIBS), located in southern Rhode Island.

\begin{tabular}{|c|c|c|c|c|c|c|}
\hline \multirow[b]{3}{*}{ Species $^{\text {a }}$} & \multicolumn{3}{|c|}{ KWRS } & \multicolumn{3}{|c|}{ BIBS } \\
\hline & \multirow[b]{2}{*}{ Trend $^{\mathrm{b}}$} & \multicolumn{2}{|c|}{$95 \% \mathrm{CI}$} & \multirow[b]{2}{*}{ Trend $^{\mathrm{b}}$} & \multicolumn{2}{|c|}{$95 \% \mathrm{CI}$} \\
\hline & & Upper & Lower & & Upper & Lower \\
\hline \multicolumn{7}{|l|}{ Neotropical-nearctic migrants } \\
\hline Red-eyed Vireo (Vireo olivaceus) & $-3.1 * * *$ & -4.4 & -1.7 & $-5.0 * * *$ & -7.4 & -2.5 \\
\hline Veery $(\text { Catharus fuscescens })^{\mathrm{c}}$ & $-4.9^{* * *}$ & -6.2 & -3.7 & $-7.3^{* * *}$ & -9.1 & -5.4 \\
\hline Swainson's Thrush $(\text { C. ustulatus })^{\mathrm{c}}$ & $-2.8 * * *$ & -4.1 & -1.5 & $-5.8 * * *$ & -8.4 & -3.2 \\
\hline Magnolia Warbler (Setophaga magnolia) & -0.9 & -2.2 & 0.3 & $-2.5^{*}$ & -4.6 & -0.4 \\
\hline $\begin{array}{l}\text { Black-throated Blue Warbler } \\
\quad(\text { S. caerulescens })^{\mathrm{c}}\end{array}$ & $3.2^{* * *}$ & 1.7 & 4.8 & 0.2 & -1.3 & 1.8 \\
\hline Blackpoll Warbler $(\text { S. striata })^{\mathrm{c}}$ & -0.9 & -4.1 & 2.2 & $-5.2 * * *$ & -7.6 & -2.7 \\
\hline Black-and-white Warbler (Mniotilta varia) ${ }^{\mathrm{c}}$ & -0.7 & -2.4 & 0.8 & $-3.5^{* * *}$ & -5.0 & -2.0 \\
\hline American Redstart (Setophaga ruticilla) & $-4.9 * * *$ & -6.7 & -3.1 & $-2.8 * * *$ & -4.1 & -1.4 \\
\hline Ovenbird (Seiurus aurocapilla) & $-1.6^{*}$ & -3.1 & -0.1 & $-3.5^{* * *}$ & -4.7 & -2.2 \\
\hline $\begin{array}{c}\text { Northern Waterthrush (Parkesia } \\
\text { noveboracensis) }\end{array}$ & 0.2 & -1.5 & 1.8 & $-3.8 * *$ & -6.0 & -1.7 \\
\hline Canada Warbler (Cardellina canadensis) & $-2.7 * * *$ & -3.8 & -1.5 & $-4.2 * *$ & -6.5 & -1.9 \\
\hline \multicolumn{7}{|l|}{ Nearctic migrants } \\
\hline House Wren (Troglodytes aedon) & $-2.7 * * *$ & -3.9 & -1.5 & -1.1 & -2.9 & -0.8 \\
\hline Golden-crowned Kinglet (Regulus satrapa) & $1.5+$ & -0.2 & 3.1 & -1.1 & -4.1 & 1.9 \\
\hline Ruby-crowned Kinglet $(R$. calendula $)$ & $-2.0 * *$ & -3.3 & -0.7 & -1.4 & -3.5 & 0.7 \\
\hline Hermit Thrush $(\text { Catharus guttatus })^{\mathrm{c}}$ & -0.7 & -2.3 & 0.9 & $-3.7 * * *$ & -5.4 & -2.0 \\
\hline American Robin (Turdus migratorius) & $-3.7 * *$ & -6.1 & 1.4 & $-3.7 * * *$ & -5.2 & -2.2 \\
\hline $\begin{array}{l}\text { Yellow-rumped Warbler (Setophaga } \\
\text { coronata) }\end{array}$ & $-3.2+$ & -6.9 & 0.5 & $-8.1^{* * *}$ & -11.7 & -4.6 \\
\hline Eastern Towhee (Pipilo erythrophthalmus) & $-3.0 * * *$ & -4.6 & -1.5 & -1.1 & -2.8 & 0.5 \\
\hline Song Sparrow $(\text { Melospiza melodia })^{\mathrm{c}}$ & $-6.6^{* * *}$ & -8.0 & -5.2 & $-3.6^{*}$ & -6.3 & -0.8 \\
\hline Swamp Sparrow (M. georgiana) & -1.9 & -4.1 & 0.4 & -1.1 & -3.2 & 1.0 \\
\hline $\begin{array}{l}\text { White-throated Sparrow (Zonotrichia } \\
\text { albicollis) }\end{array}$ & $-2.8^{* *}$ & -4.6 & -1.0 & $-3.1^{* *}$ & -5.3 & -0.9 \\
\hline Dark-eyed Junco (Junco hyemalis) & $-5.4 * * *$ & -7.7 & -3.1 & $-3.0 * * *$ & -4.6 & -1.5 \\
\hline \multicolumn{7}{|l|}{ Neotropical-nearctic migrants } \\
\hline Common Yellowthroat (Geothlypis trichas) ${ }^{\mathrm{c}}$ & $-1.8^{* *}$ & -3.1 & -0.5 & -1.0 & -2.9 & 0.9 \\
\hline Gray Catbird (Dumetella carolinensis) ${ }^{\mathrm{c}}$ & $-3.7 * * *$ & -5.2 & -2.2 & -0.1 & -1.8 & 1.7 \\
\hline
\end{tabular}

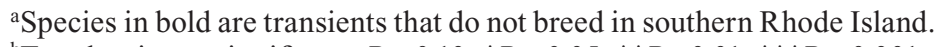

${ }^{b}$ Trend estimate significant: $P<0.10 ;{ }^{*} P<0.05 ; * * P<0.01 ; * * * P<0.001$.

'Slopes at KWRS and BIBS differ significantly. 

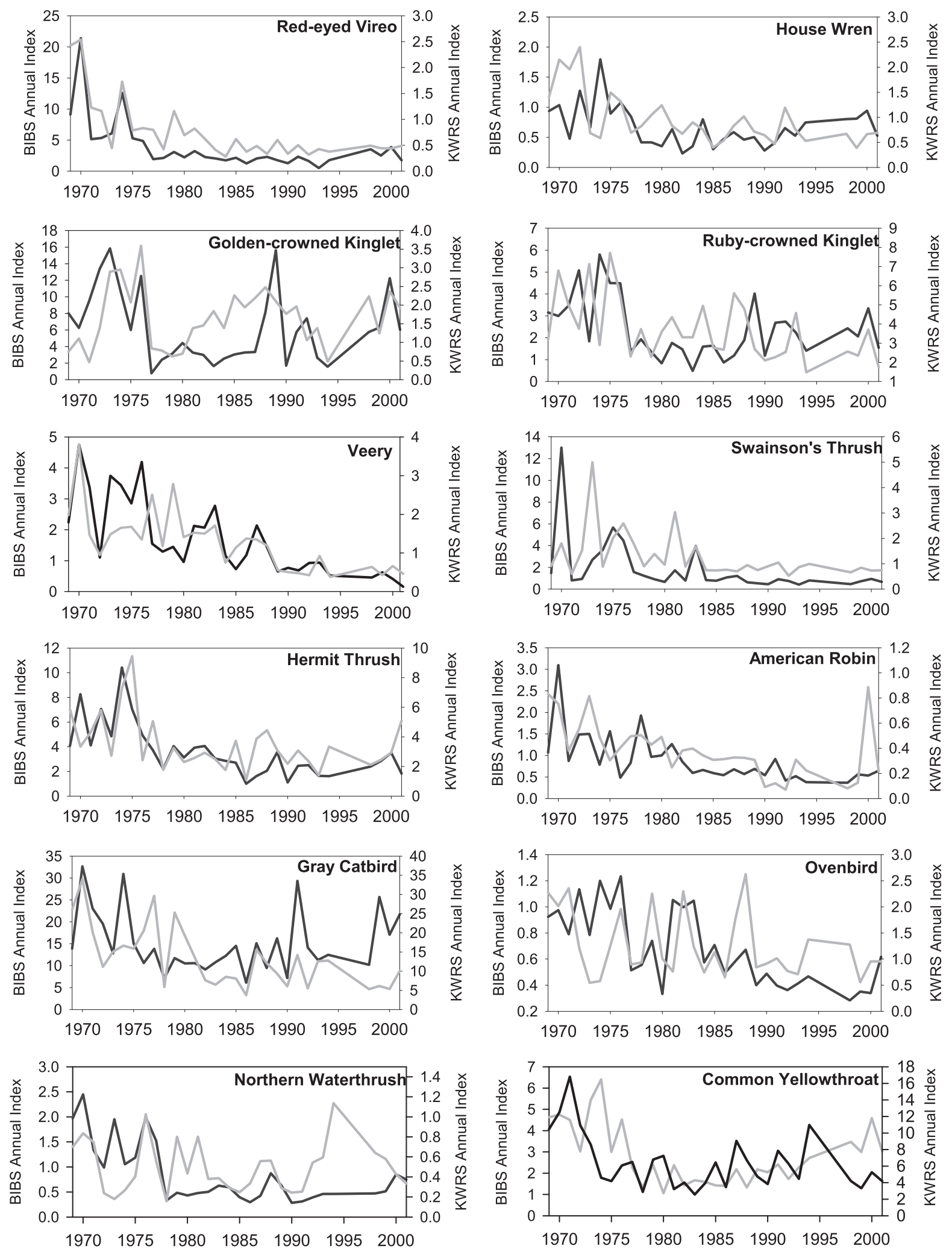

FIGURE 1. Continued. 

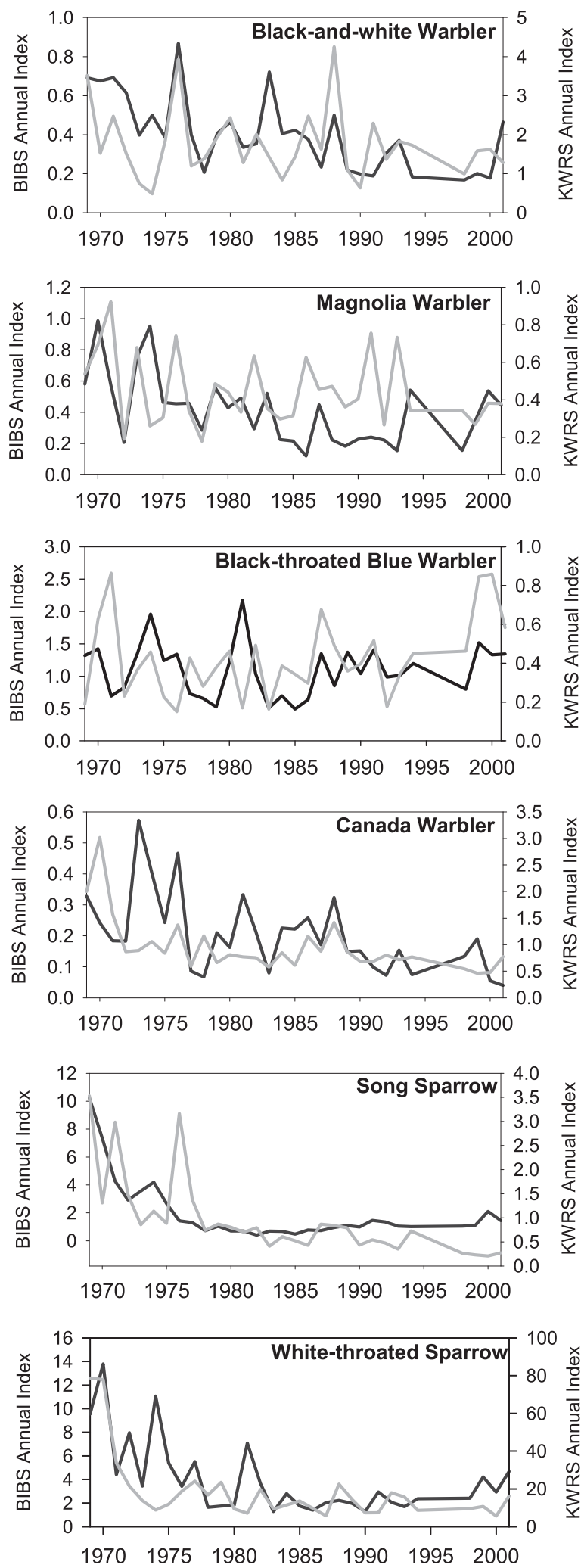
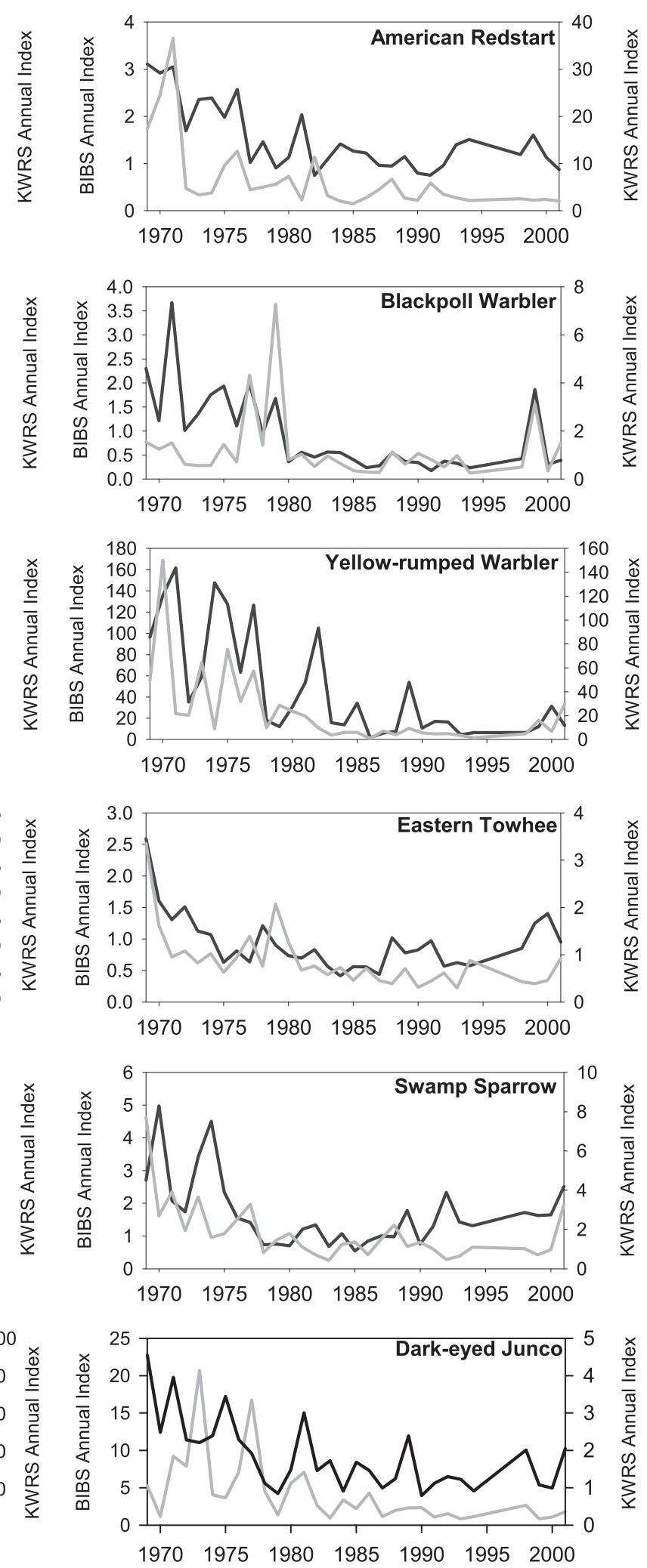

FIGURE 1. Annual population indices for 24 species of migratory passerines captured from 1969 to 2001 (1995-1997 excluded) at two constant-effort mist-netting stations in Rhode Island: Kingston Wildlife Research Station (gray lines) and the Block Island Banding Station (black lines). 
migrant (Table 1). A linear trend was significant in 18 species at KWRS and 16 species at BIBS. In no species was a significant linear trend at the two stations opposite. Only two species increased significantly. For one neotropical migrant, the Blackthroated Blue Warbler (Setophaga caerulescens), the linear increase was significant at KWRS but not at BIBS. The Goldencrowned Kinglet (Regulus satrapa), a nearctic migrant, increased significantly at KWRS and showed a nonsignificant negative trend at BIBS.

There was some concordance between the stations in annual indices. The indices were significantly correlated in $54 \%$ of the species, correlations being greatest $\left(r_{\mathrm{s}}>0.6\right)$ for three neotropical migrants, the Veery (Catharus fuscescens), Red-eyed Vireo (Vireo olivaceus), and Blackpoll Warbler (Setophaga striata), and one nearctic migrant, the Yellowrumped Warbler (S. coronata) (Table 2). Species whose annual indices were not correlated included five species of neotropical migrants and two nearctic migrants. Of the nine transient species, annual indices were significantly correlated for five.

In general, relationships between detrended annual indices were not strong, with correlations significant for only $25 \%$ of species and strong $(r>0.6)$ for the Blackpoll Warbler only. Species that had significant correlations included 5 of 11 neotropical migrants, 3 of 11 nearctic migrants, 1 of 2 mixeddistance migrants, and 4 of 9 transients.

In $92 \%$ of the species the direction of the trend's slope agreed $(G=1.42, P>0.05)$. All species that exhibited significant trends at the three banding stations were in the same slope direction. Trends estimated at all banding stations for all species except the Black-throated Blue Warbler were negative (Table 3). Trends at the banding stations were more likely to be negative than those estimated from BBS surveys in any of the Bird Conservation Regions. The percentage of declining species was $88 \%$ at KWRS (21 of 24 species), $96 \%$ at BIBS, and $96 \%$ at Manomet but $79 \%$ in BCR $30,67 \%$ in BCR $14,50 \%$ in BCR 8 , and $54 \%$, in eastern BBS routes as a whole.

Linear trends estimated for the 24 species pooled were not significantly correlated between KWRS and BIBS, but they were correlated between KWRS and Manomet and between BIBS and Manomet (Table 4). Trends estimated for the nine transient species pooled were correlated in all three pairwise comparisons of the three sites. For the 15 species that do breed in southern Rhode Island there were no correlations between the banding stations: KWRS vs. BIBS $\left(r_{\mathrm{s}}=0.06, P=0.84\right)$; KWRS vs. Manomet $\left(r_{\mathrm{s}}=0.15, P=0.58\right)$; BIBS vs. Manomet $\left(r_{\mathrm{s}}=0.10, P=0.72\right)$. Linear slopes estimated for KWRS and BIBS differed significantly $(P<0.05)$ for $38 \%$ of the species included in the analysis (Table 1). For all 24 species pooled, the trend estimated from KWRS was significantly correlated with the trend estimated from the BBS in BCR 12 (Boreal Hardwood Transition) and all eastern routes combined (Table
TABLE 2. Correlation between annual population indices and detrended annual indices at Kingston Wildlife Research Station and Block Island Banding Station for 24 species of migratory birds.

\begin{tabular}{|c|c|c|c|c|}
\hline \multirow[b]{2}{*}{ Species $^{\mathrm{a}}$} & \multicolumn{2}{|c|}{ Annual index } & \multicolumn{2}{|c|}{$\begin{array}{l}\text { Detrended } \\
\text { annual index }\end{array}$} \\
\hline & $r_{\mathrm{s}}^{\mathrm{b}}$ & $P$ & $r$ & $P$ \\
\hline \multicolumn{5}{|l|}{ Neotropical migrants } \\
\hline Red-eyed Vireo & 0.720 & $<0.001$ & 0.339 & 0.067 \\
\hline Veery & 0.822 & $<0.001$ & 0.328 & 0.076 \\
\hline Swainson's Thrush & 0.579 & 0.001 & 0.484 & 0.007 \\
\hline Magnolia Warbler & 0.180 & 0.340 & 0.050 & 0.792 \\
\hline $\begin{array}{l}\text { Black-throated Blue } \\
\text { Warbler }\end{array}$ & 0.253 & 0.177 & -0.032 & 0.866 \\
\hline Blackpoll Warbler & 0.637 & $<0.001$ & 0.675 & $<0.001$ \\
\hline Black-and-white Warbler & 0.271 & 0.148 & 0.348 & 0.059 \\
\hline American Redstart & 0.206 & 0.274 & -0.167 & 0.378 \\
\hline Ovenbird & 0.308 & 0.098 & 0.215 & 0.255 \\
\hline Northern Waterthrush & 0.273 & 0.144 & 0.278 & 0.137 \\
\hline Canada Warbler & 0.500 & 0.005 & 0.101 & 0.594 \\
\hline \multicolumn{5}{|l|}{ Nearctic migrants } \\
\hline House Wren & 0.227 & 0.227 & -0.025 & 0.896 \\
\hline Golden-crowned Kinglet & 0.387 & 0.035 & 0.528 & 0.003 \\
\hline Ruby-crowned Kinglet & 0.323 & 0.082 & 0.185 & 0.329 \\
\hline Hermit Thrush & 0.458 & 0.011 & 0.372 & 0.042 \\
\hline American Robin & 0.514 & 0.004 & 0.195 & 0.301 \\
\hline Yellow-rumped Warbler & 0.699 & $<0.001$ & 0.365 & 0.047 \\
\hline Eastern Towhee & 0.318 & 0.086 & -0.023 & 0.904 \\
\hline Song Sparrow & 0.405 & 0.027 & -0.029 & 0.879 \\
\hline Swamp Sparrow & 0.394 & 0.031 & -0.095 & 0.618 \\
\hline White-throated Sparrow & 0.303 & 0.103 & -0.085 & 0.654 \\
\hline Dark-eyed Junco & 0.543 & 0.002 & 0.287 & 0.125 \\
\hline \multicolumn{5}{|l|}{ Neotropical-nearctic migrants } \\
\hline Common Yellowthroat & 0.378 & 0.039 & 0.054 & 0.778 \\
\hline Gray Catbird & 0.341 & 0.065 & 0.389 & 0.034 \\
\hline
\end{tabular}

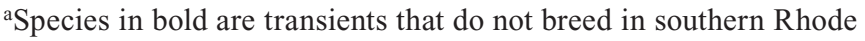
Island.

${ }^{\mathrm{b}}$ Spearman rank correlation coefficient.

4), while the trend estimated from BIBS was not significantly correlated with that estimated from any set of BBS routes.

Trends from BBS routes in four BCRs were not correlated with those at KWRS or BIBS. However, trends from BCR 8, BCR 12, and eastern BBS routes combined were significantly correlated with trends reported from Manomet.

The direction of the slope of the trend at BIBS and Manomet agreed in all nine species of transients. It agreed in eight of the nine in the comparisons of KWRS with Manomet and of KWRS with BIBS. This high degree of agreement in trend direction did not apply to comparisons of trends at the three southern New England banding stations to those estimated from five BBS strata. Slope directions at KWRS and BIBS had the most concordance with those in BCRs 14 and 12 , in 7 of 9 species at KWRS and in 6 or 9 at BIBS. 
TABLE 3. Linear population trends from 1969 to 2001 in 24 species of migratory birds at three southern New England banding stations (Kingston Wildlife Research Station [KWRS], Block Island Banding Station [BIBS], Manomet Center for Conservation [Manomet; LloydEvans and Atwood 2004]) and according to Breeding Bird Surveys (BBS) in four Bird Conservation Regions (NACBI 2011) and eastern North American BBS routes.

\begin{tabular}{|c|c|c|c|c|c|c|c|c|}
\hline \multirow[b]{2}{*}{ Species $^{\mathrm{a}}$} & \multirow[b]{2}{*}{$\mathrm{KWRS}^{\mathrm{b}}$} & \multirow[b]{2}{*}{$\mathrm{BIBS}^{\mathrm{b}}$} & \multirow[b]{2}{*}{ Manomet $^{\mathrm{b}}$} & \multicolumn{4}{|c|}{ Bird Conservation Region } & \multirow[b]{2}{*}{$\begin{array}{l}\text { Eastern } \\
\text { BBS } \\
\text { routes }^{b}\end{array}$} \\
\hline & & & & $\begin{array}{l}\text { 30: New } \\
\text { England }\end{array}$ & $\begin{array}{c}\text { 14: Atlantic } \\
\text { Northern } \\
\text { Forests }^{\mathrm{b}}\end{array}$ & $\begin{array}{l}\text { 8: Boreal } \\
\text { Softwood } \\
\text { Shield }^{b}\end{array}$ & $\begin{array}{l}\text { 12: Boreal } \\
\text { Hardwood } \\
\text { Transition }^{b}\end{array}$ & \\
\hline Red-eyed Vireo & -3.10 & -5.00 & -1.06 & -0.89 & 1.29 & 1.38 & 1.25 & 1.15 \\
\hline House Wren & -2.70 & -1.10 & -1.00 & -0.93 & -1.13 & -0.50 & -0.93 & -0.11 \\
\hline Golden-crowned Kinglet & 1.50 & -1.10 & -0.72 & 1.93 & 4.05 & 1.55 & 3.10 & 1.93 \\
\hline Ruby-crowned Kinglet & -2.00 & -1.40 & -1.09 & -2.12 & -2.12 & 0.06 & -3.46 & -0.29 \\
\hline Veery & -4.90 & -7.30 & -1.28 & -1.15 & -1.92 & 2.81 & -1.44 & -0.69 \\
\hline Swainson's Thrush & -2.80 & -5.80 & -1.69 & -1.15 & -2.26 & -0.58 & -0.32 & -1.15 \\
\hline Hermit Thrush & -0.70 & -3.70 & -0.50 & -1.42 & 1.76 & 0.79 & 2.00 & 1.38 \\
\hline American Robin & -3.70 & -3.70 & -1.78 & -0.18 & -0.32 & -0.25 & 0.59 & 0.39 \\
\hline Gray Catbird & -3.70 & -0.10 & -0.88 & 0.21 & -1.99 & 0.99 & -1.63 & -0.40 \\
\hline Magnolia Warbler & -0.90 & -2.50 & -0.38 & 0.40 & 0.32 & 1.71 & 2.11 & 1.38 \\
\hline Black-throated Blue Warbler & 3.20 & 0.20 & 1.31 & -0.90 & 1.28 & 4.12 & 2.39 & 2.10 \\
\hline Yellow-rumped Warbler & -3.20 & -8.10 & -1.94 & 0.95 & 1.79 & 0.20 & 0.45 & 0.64 \\
\hline Blackpoll Warbler & -0.90 & -5.20 & -2.22 & -8.80 & -3.58 & -5.31 & -9.15 & -8.87 \\
\hline Black-and-white Warbler & -0.70 & -3.50 & -1.59 & -2.88 & -1.11 & 0.24 & 0.08 & 0.05 \\
\hline American Redstart & -4.90 & -2.80 & -1.72 & -0.50 & -1.86 & 1.31 & -0.40 & -0.05 \\
\hline Common Yellowthroat & -1.80 & -1.00 & -1.38 & -1.93 & -0.82 & -1.46 & -0.63 & -0.97 \\
\hline Northern Waterthrush & 0.20 & -3.80 & -1.59 & -1.19 & -0.96 & -1.65 & 2.18 & 0.57 \\
\hline Ovenbird & -1.60 & -3.50 & -0.59 & -0.59 & 0.10 & 0.69 & 0.17 & 0.46 \\
\hline Canada Warbler & -2.70 & -4.20 & -1.13 & -7.36 & -3.78 & -1.76 & -3.20 & -2.52 \\
\hline Eastern Towhee & -3.00 & -1.10 & -2.41 & -5.93 & -7.69 & -5.93 & -3.06 & -1.60 \\
\hline Song Sparrow & -6.60 & -3.60 & -0.97 & -1.39 & -0.98 & -1.99 & -1.40 & -0.99 \\
\hline Swamp Sparrow & -1.90 & -1.10 & -0.06 & -1.27 & 0.92 & -0.06 & 1.91 & 0.78 \\
\hline White-throated Sparrow & -2.80 & -3.10 & -1.34 & -9.04 & -1.75 & -0.36 & -0.31 & -0.50 \\
\hline Dark-eyed Junco & -5.40 & $-\mathbf{3 . 0 0}$ & -2.00 & 0.67 & -0.90 & -0.98 & -0.12 & -1.42 \\
\hline
\end{tabular}

aSpecies in boldface are transients that do not breed in southern Rhode Island.

${ }^{b}$ Trends in boldface are significant, $P<0.05$.

TABLE 4. Correlations between estimates of population trends in birds captured at three banding stations in southern New England and along Breeding Bird Survey routes in four Bird Conservation Regions and along routes in eastern North America. Correlation coefficients above the diagonal are for 24 species of migratory birds, while coefficients below the diagonal are for 9 transient species (see Table 3 ).

\begin{tabular}{|c|c|c|c|c|c|c|c|c|}
\hline & \multirow[b]{2}{*}{ KWRS } & \multirow[b]{2}{*}{ BIBS } & \multirow[b]{2}{*}{ Manomet } & \multicolumn{4}{|c|}{ Bird Conservation Region } & \multirow[b]{2}{*}{$\begin{array}{c}\text { Eastern } \\
\text { BBS routes }\end{array}$} \\
\hline & & & & $\begin{array}{l}\text { 30: New } \\
\text { England }\end{array}$ & $\begin{array}{c}\text { 14: Atlantic } \\
\text { Northern Forests }\end{array}$ & $\begin{array}{l}\text { 8: Boreal } \\
\text { Softwood } \\
\text { Shield }\end{array}$ & $\begin{array}{l}\text { 12: Boreal } \\
\text { Hardwood } \\
\text { Transition }\end{array}$ & \\
\hline KWRS & & $0.23^{\mathrm{a}}(0.27)$ & $0.40(0.05)$ & $-0.19(0.38)$ & $0.31(0.14)$ & $0.17(0.43)$ & $0.45(0.02)$ & $0.48(0.01)$ \\
\hline BIBS & $0.70(0.03)$ & & $0.40(0.05)$ & $0.09(0.67)$ & $0.08(0.71)$ & $0.15(0.48)$ & $0.07(0.71)$ & $0.19(0.37)$ \\
\hline Manomet & $0.67(0.04)$ & $0.77(0.01)$ & & $0.16(0.44)$ & $0.47(0.02)$ & $0.56(0.01)$ & $0.42(0.04)$ & $0.61(0.01)$ \\
\hline New England & $-0.01(0.95)$ & $0.17(0.64)$ & $0.17(0.64)$ & & $0.56(<0.01)$ & $0.55(<0.01)$ & $0.50(0.01)$ & $0.50(0.01)$ \\
\hline $\begin{array}{l}\text { Atlantic Northern } \\
\text { Forests }\end{array}$ & $0.21(0.55)$ & $0.38(0.29)$ & $0.50(0.15)$ & $0.82(<0.01)$ & & $0.51(0.01)$ & $0.86(<0.01)$ & $0.83(<0.01)$ \\
\hline $\begin{array}{l}\text { Boreal Softwood } \\
\text { Shield }\end{array}$ & $0.57(0.10)$ & $0.60(0.08)$ & $0.90(<0.01)$ & $0.43(0.22)$ & $0.75(0.02)$ & & $0.50(0.01)$ & $0.73(<0.01)$ \\
\hline $\begin{array}{l}\text { Boreal Hardwood } \\
\text { Transition }\end{array}$ & $0.38(0.29)$ & $0.52(0.14)$ & $0.65(0.05)$ & $0.75(0.01)$ & $0.93(<0.01)$ & $0.80(<0.01)$ & & $0.87(<0.01)$ \\
\hline Eastern BBS & $0.60(0.08)$ & $0.63(0.06)$ & $0.88(<0.01)$ & $0.48(0.17)$ & $0.80(<0.01)$ & $0.98(<0.01)$ & $0.83(<0.01)$ & \\
\hline
\end{tabular}

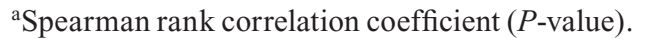




\section{DISCUSSION}

This study provides evidence that nearby banding stations yield similar results when monitoring long-term trends in population indices; however, extraneous variables may confound the results' precision. We measured the degree of conformity between a station on the mainland, KWRS, and one on an offshore island, BIBS, by three techniques. The most convincing evidence was the direction of the trends for individual species. We found concordance in this direction in all species with a significant trend at the two stations. In fact, except for the Northern Waterthrush (Parkesia noveboracensis ) and Golden-crowned Kinglet, the direction of the slopes of all species agreed. Dunn et al. (1997) also documented high concordance in population-trend estimates at two nearby banding stations, while Lloyd-Evans and Atwood (2004) and Rimmer et al. (2004) found no similarity in trend estimates for migration-monitoring stations at least $250 \mathrm{~km}$ apart.

During our study, long-distance migrants were more likely to have had a significant linear decline at the offshore island station (10 of 11 species at BIBS) than at the mainland station (6 of 11 species at KWRS), but a similar number of shortdistance migrants were declining (7 of 11 species at KWRS; 5 of 11 species at BIBS). In contrast, both the Gray Catbird (Dumetella carolinensis) and Common Yellowthroat (Geothlypis trichas), the two mixed-distance migrants, declined significantly at KWRS, while their trends on Block Island were relatively stable. Reasons for these differences are unclear.

We also tested for differences in yearly fluctuations as another indication that these two banding stations might be tracking populations in a similar fashion. But the correlation between yearly fluctuations in indices of numbers captured was weak. Only $54 \%$ of the species were significantly correlated, and just four species had correlation coefficients $>0.6$. If there were a strong long-term trend, then correlations in annual indices may have been influenced by this trend. The results indicate that perhaps a lack of a strong overall longterm trend in the majority of species or that other influences weighed too heavily on the annual fluctuations.

Detrended indices are uninfluenced by long-term trends so may more accurately represent differences in the actual yearly fluctuations between sites, especially when rates of change at the sites differ. In the detrended indices, there was less agreement between KWRS and BIBS, only $25 \%$ of 24 species showing significant correlations. This low percentage suggests that extraneous variables, such as local weather effects, may have influenced yearly fluctuations in captures (Richardson 1990, Dunn and Hussell 1995). By logtransforming mist-net captures we were able to reduce the influence of aberrant days often induced by local weather conditions (Dunn et al. 1997).

Differences in trends estimated at KWRS and BIBS could also be attributed to the rate of change in habitat structure at the two stations, as increases in vegetation height could depress the nets' rate of capture (Remsen and Good 1996, Wang and Finch 2002, Mallory et al.2004). Several authors have emphasized the importance of maintaining a stable height and composition of vegetation at banding stations (Ballard et al. 2003, Dunn and Ralph 2004), which unfortunately was not economically feasible or practical at either of the stations in Rhode Island. In addition, since vegetation structure was not measured through the study at either BIBS or KWRS, it was not possible to model the effects of vegetation change on capture rates.

\section{REGIONAL TREND COMPARISON}

Trends of transient species at KWRS, BIBS, and Manomet were significantly correlated, providing compelling evidence that a network of migration-monitoring stations could track migratory populations, as has been done successfully in southern Canada by the Canadian Migration Monitoring Network (Crewe et al. 2008). Conversely, with the exception of trends at Manomet with some BBS strata, few of the trends estimated from the banding stations were significantly correlated with those estimated from selected BBS strata (Lloyd-Evans and Atwood 2004, Rimmer et al. 2004).

Discrepancies in slope directions between estimates from banding stations and those from BBS data could be due to a number of factors. We were uncertain about the breeding origin of birds captured at KWRS and BIBS, so we selected the BBS strata that we believed most relevant to migrants through southern New England (Lloyd-Evans and Atwood 2004). KWRS and BIBS may sample a wider portion of ranges than the BBS strata we used, particularly for species such as the Blackpoll Warbler, which stages along the Atlantic coast during the fall before embarking on a transatlantic flight (Nisbet et al. 1995). Finally, data on fall migrants along the coast are highly skewed toward juveniles (Dunn and Nol 1980, Ralph 1981), which may not accurately reflect the population trends of species.

All three of the banding stations had more declines in transient species than did the BBS. Steeper declines at banding stations may be an artifact of the sampling design or the result of a stronger influence of vegetation change at banding stations than in point counts. That is, successional changes in vegetation affect the trends of species detected by both point counts and mist nets negatively or positively. However, habitat preferences in conjunction with decreased capture probabilities associated with increased vegetation height may accelerate observed decreases in captures. It is, of course, also possible that the banding stations may be tracking migrants' populations more precisely than is the BBS.

Declines were evident in 21 of 24 species we monitored. BBS data imply precipitous long-term declines in many birds breeding in the Northeast (Sauer et al. 2003, Rich et al. 2004). The Black-throated Blue Warbler was the only long-distance migrant whose trends at KWRS and BIBS were increasing or stable. Evidence of a positive trend for this species in the 
Northeast has now been supported by several independent sources (Holmes and Sherry 2001, Lloyd-Evans and Atwood 2004) and different monitoring techniques. This type of verification of trends is needed from multiple monitoring programs.

\section{FUTURE NEEDS}

Our study provides convincing evidence that nearby banding stations have the ability to track avian populations similarly. Considerable fluctuations in the banding data emphasize the need for standardization of monitoring techniques and controlling for extraneous variables. Banding stations could provide a useful means of tracking avian population trends with significantly fewer personnel than current large-scale monitoring programs require. However, it is increasingly clear that each monitoring technique has its own suite of limitations and that it is best to validate results by several independent techniques (Porzig et al. 2011). BBS routes are spatially explicit, so the locations of declining populations can be determined, whereas the origin of birds captured at banding stations are currently unknown (but see Wassenaar and Hobson 2001, Langin et al. 2007). However, the BBS does not monitor large areas of Canada or extreme boreal regions where the vast majority of the birds in question breed (Dunn et al. 1997, Rich et al. 2004), while migration stations may be capable of monitoring these more northerly populations.

Currently, we can only hypothesize where the species monitored at stopover sites breed or winter on the basis of each species' life history. The usefulness of data from migration stations will be greatly expanded when biologists are able to determine the origin of sampled populations (Wassenaar and Hobson 2001, Langin et al. 2007). The identification of which populations are monitored by individual banding stations needs to be addressed if migration data are to be used to their fullest extent in monitoring birds' population trends.

\section{ACKNOWLEDGMENTS}

We thank D. Kraus, E. Lapham, and H. Lapham, for without their foresight in initiating banding programs at Kingston and on Block Island, this research would not have been possible. We also thank the following people who were integral in the collection of the data: B. Pierce, K. Gaffett, S. Reinert, S. Comings, M. Whitman, B. Hylton, K. McPherson, and P. Miller. We are very grateful to D. Hussell and E. Dunn for their statistical guidance, insight, and invaluable review of drafts. We also thank E. Dunn, H. Ginsburg, S. McWilliams, and T. Tyrrell, and an anonymous reviewer for comments on earlier drafts. This is contribution 5283 from the Rhode Island Agricultural Experiment Station.

\section{LITERATURE CITED}

American Ornithologists' Union (AOU). 1998. Check-list of North American birds, 7th ed. American Ornithologists' Union, Washington, DC.

Ballard, G., G. R. Geupel, N. Nur, and T. Gardali. 2003. Long-term declines and decadal patterns in population trends of songbirds in western North America, 1979-1999. Condor 105:737-755.
Bart, J., K. P. Burnham, E. H. Dunn, C. M. Francis, and C. J. RALPH. 2004. Goals and strategies for estimating trends in landbird abundance. Journal of Wildlife Management 68:611-626.

Caughley, G., AND A. GunN. 1996. Conservation biology in theory and practice. Blackwell Science, Cambridge, MA.

Crewe, T. L., J. D. McCracken, P. D. Taylor, D. Lepage, and A. E. Heagy. 2008. The Canadian Migration Monitoring NetworkRéseau canadien de surveillance des migrations: ten-year report on monitoring landbird population change. CMMN-RCSM Scientific Technical Report 1. Bird Studies Canada, Port Rowan, Canada.

DeGraAf, R. M., and J. H. Rappole. 1995. Neotropical migratory birds: natural history, distribution, and population change. Cornell University Press, Ithaca, NY.

Drury, W. H., AND J. A. KeITH. 1962. Radar studies of songbird migration in coastal New England. Ibis 104:449-489.

DunN, E. H. 2005. Counting migrants to monitor bird populations: state of the art. USDA Forest Service General Technical Report PSW-GTR-191.

DunN, E. H., AND D. J. T. Hussell. 1995. Using migration counts to monitor landbird populations: review and evaluation of current status. Current Ornithology 12:43-88.

Dunn, E. H., D. J. T. Hussell, And R. J. Adams. 1997. Monitoring songbird population change with autumn mist netting. Journal of Wildlife Management 61:389-396.

DunN, E. H., AND E. Nol. 1980. Age-related migration behavior of warblers. Journal of Field Ornithology 51:254-269.

DunN, E. H., AND C. J. RALPH. 2004. Use of mist nets as a tool for bird population monitoring. Studies in Avian Biology 29:1-6.

ENSER, R.W. 1992. The atlas of breeding birds in Rhode Island. Rhode Island Department of Environmental Management, Providence, RI.

Francis, C. M., AND D. J. T. Hussell. 1998. Changes in numbers of land birds counted in migration at Long Point Bird Observatory, 1961-1997. Bird Populations 4:37-66.

GeIssler, P. H., AND B. R. NoON. 1981. Estimates of avian population trends from the North American Breeding Bird Survey. Studies in Avian Biology 6:42-51.

Hagan, J. M., T. L. Lloyd-Evans, J. L. Atwood, and D. S. Wood. 1992. Long-term changes in migratory landbirds in the northeastern United States: evidence from migration capture data, p. 115-130. In J. M. Hagan III and D. W. Johnston [EDS.], Ecology and conservation of neotropical migrant landbirds. Smithsonian Institution Press, Washington, DC.

Holmes, R. T., AND T. W. SHERRY. 2001. Thirty-year bird population trends in an unfragmented temperate deciduous forest: importance of habitat change. Auk 118:589-609.

Hussell, D. J. T. 1981. The use of migration counts for monitoring bird population levels. Studies in Avian Biology 6:92-102.

Hussell, D. J. T., M. H. Mather, And P. H. Sinclair. 1992. Trends in numbers of tropical- and temperate-wintering migrant landbirds in migration at Long Point, Ontario, 1961-1998, p. 101-114. In J. M. Hagan III and D. W. Johnston [EDS.], Ecology and conservation of neotropical migrant landbirds. Smithsonian Institution Press, Washington, DC.

Langin, K. M., M. W. Reudink, P. P. Marra, D. R. Norris, T. K. KYSER, AND L. M. RATCLIFFE. 2007. Hydrogen isotopic variation in migratory bird tissues of known origin: implications for geographic assignment. Oecologica 152:449-457.

Lloyd-Evans, T. L., AND J. L. ATwOOD. 2004. 32 years of changes in passerine numbers during spring and fall migrations in coastal Massachusetts. Wilson Bulletin 116:1-16.

Mallory, E. P., N. V. L. Brokaw, And S. C. Hess. 2004. Coping with capture rate bias: canopy height and several extrinsic factors. Studies in Avian Biology 29:151-160. 
North American Bird Conservation Initiative [online]. 2011. Bird conservation regions. <http://www.nabci-us.org/bcrs.htm> (23 February 2012).

Nisbet, I. C. T., D. B. McNair, W. Post, And T. C. Williams. 1995. Transoceanic migration of the Blackpoll Warbler: summary of scientific evidence and response to criticisms by Murray. Journal of Field Ornithology 66:612-622.

OsENKOWSKI, J. E. 2002. Validating the use of banding data to monitor avian population trends: a comparison of two adjacent banding stations. M.Sc. thesis, University of Rhode Island, Kingston, RI.

Pagen, R. W., F. R. Thompson III, and D. E. Burhans. 2002. A comparison of point-count and mist net detections of songbirds by habitat and time of season. Journal of Field Ornithology 73:53-59.

Porzig, E. L., K. E. Dybala, T. Gardali, G. Ballard, G. R. Geupel, AND J. A. Wiens. 2011. Forty-five years and counting: reflections from the Palomarin Field Station on the contribution of long-term monitoring and recommendations for the future. Condor 113:713-723.

RALPH, C. J. 1981. Age ratios and their possible use in determining autumn routes of passerine migrants. Wilson Bulletin 93:164-188.

Reinert, S. E., E. Lapham, and K. Gaffet. 2003. Landbird migration on Block Island: community composition and conservation implications for an island stopover habitat, $\mathrm{p}$. 151-163. In P. W. C. Paton, L. Gould, P. A. August, and A. Frost [EDS.]. Ecology of Block Island. Rhode Island Natural History Survey, Kingston, RI.

Remsen, J. V. JR., AND D. A. Good. 1996. Misuse of data from mist net captures to assess relative abundance in bird populations. Auk 113:381-398.

Rich, T. D., C. J. Beardmore, H. Berlanga, P. J. Blancher, M. S. W. Bradstreet, G. S. Butcher, D. W. Demarest, E. H. Dunn, W. C. Hunter, E. E. Iñigo-Elias, J. A. Kennedy, A. M. Martell, A. O. Panjabi, D. N. Pashley, K. V. Rosenberg, C. M.
Rustay, J. S. Wendt, And T. C. Will. 2004. Partners in Flight North American landbird conservation plan. Cornell Lab of Ornithology, Ithaca, NY.

RICHARDSON, W. J. 1990. Timing of bird migration in relation to weather: updated review, p. 78-101. In E. Gwinner [ED.], Bird migration: physiology and ecophysiology. Springer-Verlag, New York.

Rimmer, C. C., S. D. Faccio, T. L. Lloyd-Evans, and J. M. Hagan III. 2004. A comparison of constant-effort mist netting results at a coastal and inland site during migration. Studies in Avian Bio$\log$ 29:123-134.

Sauer, J. R., J. E. FAllon, And R. Johnson. 2003. Use of North American Breeding Bird Survey data to estimate population change for bird conservation regions. Journal of Wildlife Management 67:372-389.

Sauer, J. R., J. E. Hines, J. E. Fallon, K. L. Pardieck, D. J. Ziolkowski JR., AND W. A. Link. 2011. The North American Breeding Bird Survey, results and analysis 1966-2009, version 3.23.2011. USGS Patuxent Wildlife Research Center, Laurel, MD.

Sprugel, D. G. 1983. Correcting for bias in log-transformed allometric equations. Ecology 64:209-210.

SPSS, INC. 2007. Statistical packages for the social sciences, version 16. SPSS, Chicago.

WANG, Y., AND D. M. FINCH. 2002. Consistency of mist netting and point counts in assessing landbird species richness and relative abundance during migration. Condor 104:58-72.

WassenaAR, L. I., AND K. A. Hobson. 2001. A stable-isotope approach to delineate geographical catchment areas of avian migration monitoring stations in North America. Environmental Science Technology 35:1845-1850.

ZAR, J. H. 2010. Biostatistical analysis, 5th ed. Prentice Hall, Upper Saddle River, NJ. 